\title{
EDUCATING JURIES: THE BATTERED WOMAN DEFENCE IN CANADA
}

\author{
DANIEL J. BRODSKY*
}

\begin{abstract}
This article considers the possible application of the new American Battered Woman Defence in Canada. It explores this possibility paying particular regard to the provisions of the Canadian Criminal Code and the Canada Evidence Act. It includes a brief discussion of the psychological basis for the defence and an explanation of its operation in the United States.
\end{abstract}

\section{INTRODUCTION}

Wife beating has reportedly been practiced throughout human history.' However, it was not until recently that the incidence of violence within North American families has emerged as a significant and alarming social problem. ${ }^{2}$ In recent years, wife beating has become a widespread concern with the realization that it is the foremost source of physical injury to women in America. ${ }^{3}$ Law enforcement agencies report that there are more phone calls made annually reporting family violence than any other criminal activity. ${ }^{4}$ Despite this staggering statistic, the Federal Bureau of Investigation (F.B.I.) in the United States, as well as other law enforcement experts consider wife beating to be the most underreported crime in America. ${ }^{5}$ Wife abuse transcends traditional class, race and socio-economic lines. It is just as likely to occur in an affluent suburb as in an inner city ghetto. Wife abuse is almost as likely to be committed by the professional, as frequently as it is committed by the chronically unemployed. ${ }^{6}$ Currently, media attention has been focused on women, physically and psychologically abused for years, who have struck back at their batterers and killed them and have been brought to trial on the charge of murder.' In each case, the woman stated that she did not intend to kill her batterer, only to stop him from killing her. ${ }^{8}$

This paper will consider the battered woman's syndrome and characteristics of the lifestyle shared by battered women. The paper will then discuss

* 1987 Graduate from University of Alberta Faculty of Law, Student-At-Law, Greenspan, Rosenberg, Toronto.

1. M.J. Leary, "The Development of Expert Testimony on the Battered Woman Syndrome in Homicide Cases" (1985) 53 U.M.K.C. Law Review 386; M Roy, Battered Women (1977).

2. Domestic violence occurs in a large variety of permutations and combinations. This article is confined to the defence of women who have been abused by a male with whom they have had a relationship, regardless of whether they had in fact been married, living together, separated or divorced. Although many of the citations employ terms such as husband, wife, and spouse, this article is not limited to violence occuring only within marriages. That the term "Battered Woman Defence" is phrased in the feminine gender is not an indication that the same principles do not apply to battered men. See M.E. Scott, "The Battered Spouse Syndrome" (1980) 107 Virgina Medical 41.

3. Supra n. 1.

4. "Wife Beating: The Silent Crime", Time (September 5, 1983) 23.

5. D. Martin, Battered Wives (1976).

6. C.P. Ewing, Battered Women Who Kill: Psychological Self-Defence as Legal Justification (1987); R.K. Goodstein, A.W. Page, "Battered Wife Syndrome Overview of Dynamics and Treatment" (1982) 138 AM. J. Psychiatry 1036.

7. C. Cacy, "The Battered Woman's Syndrome Defense" (1985) 34 Kansas Law Review 337.

8. L.E. Walker, The Battered Woman (1979). 
the use of expert testimony in educating juries in order to dispell common misconceptions regarding the freedom of a battered woman to escape her abusive circumstances and demonstrate the reasonableness of her state of mind in acting in self-defence to prevent imminent death or serious bodily injury. ${ }^{9}$ Finally, the American case law on the battered women's defence will be comparitively reviewed with a view to demonstrating that there are no bars to the successful application of the defence in Canada.

\section{THE BATTERED WOMAN'S SYNDROME}

The phrase "battered woman's syndrome" is a descriptive term which attempts to explain the unique combination of psychological stresses that result from the deliberate and repeated infliction of mental and physical abuse. ${ }^{10}$ Dr. Lenore Walker pioneered the initial research that led to the definition of battered woman's syndrome." The term "syndrome" is a descriptive expression for an identifiable group of symptoms that occur together, the sum of which characterize the behavior and state of mind of the battered woman. ${ }^{12} \mathrm{~A}$ "battered woman" is a woman who is, or who has been, involved in a relationship having a romantic, affectionate, or sexual component with a man who repeatedly subjects or subjected her to forceful physical and/or psychological abuse. ${ }^{13}$ Two primary theories, Learned Helplessness and the Walker Cycle Theory of Violence, have received empirical support in the explanation of the behavior of battered women. ${ }^{14}$

Learned helplessness portrays a psychological condition which is based upon the finding that when an individual is subjected to repeated experiences over which she perceives she has no control or escape what may result is impairment in motivation and control of future outcome even after the uncontrollable situation disappears. ${ }^{15}$

Learned helplessness was first tested in laboratory experiments in which dogs were taught that their behavior did not make a difference to whether or not they received electric shocks. Similarly, the lack of control over one's environment was found to cause disturbances in human motivation and behavior. ${ }^{16}$ To compound the feeling of learned helplessness that a battered woman experiences, the woman may also have children and feel economically dependent upon her batterer. The battered woman may also harbor the fear that any attempt to leave the battering relationship will be met with more violence once her batterer hunts her down. Even divorced woman

9. For the purpose of this article where a defendant elects to be tried without a jury, by a judge alone, the word "jury" should be replaced with the phrase "trier of fact" as the battered woman's defence is still applicable.

10. M.A. Baumann, "Expert Testimony on the Battered Wife Syndrome: A Question of Admissibility In The Prosecution Of The Battered Wife For The Killing of Her Husband" (1983) 27 St. Louis U. Law Journal 407.

11. Supra n. 8.

12. "Admissibility of Expert Testimony" (1985) 9 M.P.D.L.R. 333.

13. L.E. Walker, The Battered Woman Syndrome (1984).

14. Ibid., See also L.E. Walker, R.K. Thyfault, A. Browne, "Beyond the Juror's Ken: Battered Women" (1982) Vermont Law Rev. 1.

15. Supran. 10.

16. M. Seligman, Helplessness: On Depression, Development and Death (1975). 
have reported that batterers follow them when they leave, harrass them and continue to beat them. ${ }^{17}$ This learned helplessness theory goes some of the way in explaining why many women become psychologically locked into their situation, and despite the fact that the women may in actuality be able to leave, they feel that they are not "free to leave".

A second theory which characterizes the behavior and state of mind of a battered woman is the Walker Cycle Theory of Violence. The Walker Cycle Theory of Violence is a tension reduction theory which purports that incidents of wife abuse occur in a patterned repetitive manner. The theory states that three distinct phases comprise a recurrent cycle in a typical battering relationship. These phases explain how a battered woman becomes victimized, falls into learned helplessness behavior, and does not attempt to escape. Dr. Walker describes the three phases as follows: ${ }^{18}$

During the first phase, there is a gradual escalation of tension displayed by discrete acts causing increased friction such as name-calling, other mean intentional behaviors, and/ or physical abuse. The batterer expresses dissatisfaction and hostility but not in an extreme or maximally explosive form. The woman attempts to placate the batterer, doing what she thinks might please him, calm him down, or at least, what will not further aggravate him. She tries not to respond to his hostile actions and uses general anger reduction techniques. Often she succeeds for a little while which reinforces her unrealistic belief that she can control this man. It also becomes part of the unpredictable noncontingency response/out-come pattern which creates the "learned helplessness".

The tension continues to escalate and eventually she is unable to continue controlling his angry response pattern. Exhausted from the constant stress, she usually withdraws from the batterer, fearing she will inadvertently set off an explosion. He begins to move more oppressively toward her as he observes her withdrawal ... Tension between the two becomes unbearable. The second phase, the acute battering incident, becomes inevitable without intervention.

Phase two is characterized by the uncontrollable discharge of the tensions that have built up during phase one. The batterer typically unleashes a barrage of verbal and physical aggression that can leave the woman severely shaken and injured. In fact, when injuries do occur it usually happens during this second phase. It is also the time police become involved, if they are called at all. The acute battering phase is concluded when the batterer stops, usually bringing with its cessation a sharp physiological reduction in tension. This in itself is naturally reinforcing. Violence often succeeds because it does work.

In phase three which follows, the batterer may apologize profusely, try to assist his victim, show kindness and remorse, and shower her with gifts and/or promises. The batterer himself may believe at this point that he will never allow himself to be violent again. The woman wants to believe the batterer and, early in the relationship at least, may renew her hope in his ability to change. This third phase provides the positive reinforcement for remaining in the relationship, for the woman.

At some point of desperation, a woman may attack her batterer in selfdefence before she is beaten, with the reasonable intention of preventing her own imminent death or serious bodily injury. It is here that expert testimony may provide a jury with the understanding of how a woman could perceive herself in imminent physical danger at the time she killed. In this context, expert testimony concerning battered woman's syndrome is central to a claim of self-defence. ${ }^{19} \mathrm{~A}$ second purpose of offering expert testimony in this regard, is to dispel common myths concerning abused

17. Supra n. 14.

18. Supra n. 13 at $95-96$.

19. T.B. Waltrip, "Evidence - The Battered Woman Syndrome in Illinois: Admissibility of Expert Testimony" (1986) II So. Ills. U.L.J. 137. 
women such as the myths that: an abused woman is "free to go" at any time, is crazy or masochistic and that her behavior is peculiar to only a small percentage of the population..$^{20}$

\section{THE BATTERED WOMAN DEFENCE IN THE UNITED STATES}

The subjective perceptions of an individual, brutalized regularly by domestic violence, are especially critical to the determination of whether her actions in purported self-defence were objectively reasonable. While it is true that a subjective demonstration of impending danger prior to the defendant's use of force is necessary, to require the battered woman to await a blatant, deadly assault before she can act in defence of herself would not only ignore unpleasant reality, but would amount to sentencing her to "murder by installment". ${ }^{21}$ As the problems of battered women have begun to receive more attention, professionals have begun to study the effects that sustained patterns of physical and psychological abuse can have on them. As noted earlier, effects of such cumulative terror are what many scientific observers have termed "the battered woman's syndrome". In order for a jury to appreciate the unique pressures that force battered women to remain with their spouses, despite their long standing and reasonable fear of severe bodily harm, in addition to the intense isolation that being a battered woman creates, juries must be educated through expert testimony regarding the battered woman's state of mind. Therefore the relevance of such expert testimony to some issue before the trier of fact must be established.

Whether expert testimony on the battered woman's syndrome should be admitted as evidence is dependant upon whether it is relevant to the defendant's claim of self-defence. Society does not punish all killings. Selfdefence exonerates a person who kills in the reasonable belief that such action is necessary to prevent their own death or serious injury, even though this belief is later proved to be mistaken. ${ }^{22}$ Justice Homes in Brown v. United States declared that: $:^{23}$

\footnotetext{
Detached reflection cannot be demanded in the presence of an uplifted knife ... it is not a condition of immunity that one in that situation should pause to consider whether a reasonable man might not think it possible to fly with safety or to disable his assailant rather than to kill him.
}

The law requires a reasonable, though not necessarily correct judgment. Honesty alone, does not suffice. A defendant claiming the privilege of selfdefence must also establish that her belief in the necessity to use force was reasonable having regard to the facts as they appeared to her at the time of

20. The incidence of battered woman's syndrome in Canada is more common than one would expect and has been estimated to be as high as 1 per 10 Canadian women. See, R.W. Swanson "Battered Wife Syndrome" (1984) 130 Can. Med. Assoc. J. 709.

21. State v. Gallegos 719 P. 2 d 1268 (N.M. App. 1986).

22. Beard v. United States 158 U.S. 550 (D.C., 1895).

23. Brown v. United states 256 U.S. 335 (D.C. 1921) at 343. 
the killing. ${ }^{24}$ The law of self-defence still applies when the danger, although reasonably perceived, is not borne out by events. ${ }^{25}$ For example, when confronted by an attacker who is known to carry a weapon and appears to be reaching for it, a person may reasonably believe herself to be in imminent danger, even if the attacker turns out to be unarmed. ${ }^{26}$ This is where expert testimony regarding the battered woman's syndrome provides the greatest assistance to juries: ${ }^{27}$

Given the circumstances of her situation when she kills, the ... wife defendants fall neither within the definition of first-degree murder nor second degree murder.

Instead, if the entire extraordinary syndrome of the battered wife is considered in the application of the elements of self-defense, she is guilty of no crime at all.

It should be noted that for the defendant to prevail, the jury need not find beyond a reasonable doubt that her belief in the amount of force necessary to prevent further attack was honest, reasonable and not retaliatory. ${ }^{28}$ Rather, if any evidence raising the issue of self-defence is adduced, either in the State's or the defendant's case, then the jury must be instructed that the State has the burden of establishing beyond a reasonable doubt that the defendant did not act in self-defence. ${ }^{29}$ The State is generally afforded a wide latitude with respect to expert testimony and will be allowed to call rebuttal evidence to repel or counteract the effect of an expert opinion which is based upon an incorrect or misleading assumption. ${ }^{30}$ If the state does not meet its burden of proving that the self-defence claim does not accord with the facts, then an acquittal is required since there remains a reasonable doubt regarding whether the defendant acted in self-defence. ${ }^{31}$

In addressing the question of relevancy the court in Fielder v. State held that testimony on the battered woman's syndrome is relevant for two primary reasons.$^{32}$ First, to dispell alleged common misconceptions usually

24. Although there is nearly universal agreement that reasonable but mistaken beliefs are acceptable bases for defensive action, there has been some disagreement among American jurisdictions as to whether an objective (State v. Kelly 478 A. 2d 364 (N.J., 1984)) or subjective (State v. Leidholm 334 N.W. 2d 811 (N.D., 1983) or hybrid standard of reasonableness should be used. ie. would an average person of ordinary sensibilities have believed the force was proportionate, necessary, and immediate under the circumstances? Or would an average person in the defendant's circumstances have believed the force was proportionate, necessary and immediate? See C.J. Rosen, "The Excuse of Self-Defence: Correcting A Historical Accident On Behalf Of Battered Women Who Kill" (1986) 36 The American University Law Review II.

25. Generally deadly force may only be used to counteract deadly force. Care must be taken to ensure that women have their conduct judged in the light of individual psychological and physical sex differences. See M.A. Buda, T.L. Butler, "The Battered Wife Syndrome: A Backdoor Assault on Domestic Violence" (1984-85) 23 Journal of Family Law 359.

26. E.M. Schneider, S.B. Jordan, "Representation of Women Who Defend Themselves in Response to Physical or Sexual Assault" (1978) 4 Women's Rights Law Reporter 149.

27. N. Fiora - Gromally (1978) "Battered Wives Who Kill Double Standard Out of Court, Single Standard In?" 2 Law and Hum. Behav. 133 at 153.

28. C.W. Kaas, "The Admissibility of Expert Testimony On The Battered Woman Syndrome In Support Of A Claim of Self-Defence" (1982) 15 Conn. L.R. 121.

29. State v. Lynch 436 So. 2d 567 (La., 1983); Commonwealth v. Zenyuh 453 A. 2d 338 (Pa.Super., 1982).

30. State v. Anaya 456 A. 2 d 1255 (Me., 1983).

31. State v. Kelly supra n. 24.

32. Fielder v. State 683 S.W. 2d 565 (Tex. App. 2 Dist., 1985). 
held by a jury that a normal or reasonable person would not remain in such an abusive relationship and secondly, to demonstrate the reasonableness of the defendant's fears that she was in imminent peril of suffering death or serious bodily injury. The jury must consider all the facts and circumstances which were subjectively known to the defendant including those known long before the killing occured..$^{33}$ Thus, the admissibility of expert testimony in this context is based upon the assumption that while an average person subjected to the same facts and circumstances surrounding an incident, ought not to fear for her life or physical well being, because the defendant is a battered woman, her actions in self-defence are justifiable. These reasons are not merely relevant; they are central to a claim of selfdefence.

Laudable as these reasons may be, the probative value of the testimony must outweigh its prejudicial impact. ${ }^{34}$ If an expert testified regarding the battered woman's syndrome, then the deceased is in effect identified as a batterer. In fact, the trial court in Ibn-Tamas v. United States excluded testimony regarding battered woman's syndrome because they said to have done otherwise would have put the deceased on trial as a batterer, and would have confused the issue before the trier of fact. ${ }^{35}$ Other judges have stated that expert testimony on battered women could so prejudice jurors that they would decide the case on the basis of typical rather than actual facts. ${ }^{36}$ The Superior Court, District of Columbia in reversing the trial court's ruling in Ibn - Tamas v. United States held with respect to relevancy, that providing the defendant establishes herself as a battered woman, the testimony regarding her perceptions and behavior at the time of the killing would be central to her claim of self-defence. ${ }^{37}$ The court further held as a matter of law that the probabtive value of the expert testimony would outweigh the risk of engendering vindictive passions within the jury or confusing the issue. ${ }^{38}$ If the defendant's identity as a battered woman is not established however, all probative value is negated and testimony on the battered woman's syndrome would be nothing more than prejudicial. ${ }^{39}$

The courts are increasingly recognizing the probative and explanatory power of expert testimony regarding battered women. However, as with any claim of self-defence, accountability is not supplanted:40

Battering husbands may well be deserving of society's condemnation. When they batter their wives they should be - and are - subject to prosecution. But they do not all deserve to be killed.

33. State v. Wanrow 559 P. 2 d 548 (Wa., 1977).

34. Ibn-Tamas v. United States 407 A. 2 d 626 (D.C., 1979).

35. Id.

36. B.C. Thompson, "Defending the Battered Wife: A Challenge For Defence Attorneys" (1986) 22 Trial 74.

37. Supra n. 34.

38. Id.

39. Id. See also State v. Dozier 255 S.E. 2 d 552 (W.Va., 1979) where the Supreme Court of West Virginia invited testimony regarding Battered Wife Syndrome where the defence elicited testimony regarding prior physical beatings in order that the jury fully evaluate and consider the defendant's mental state at the time of the offence.

40. May v. State 460 So. 2 d 778 (Miss., 1984). 
The woman claiming the privilege of self-defence must have been acting reasonably under the circumstances and apprehended her imminent death or bodily injury.

Expert testimony regarding the battered woman's syndrome is not offered to demonstrate that the batterings so affected the defendant's mental capacity that she could not tell right from wrong nor perceive the moral qualities of her act. ${ }^{41}$ In fact, testimony regarding the battered woman's syndrome has been successfully advanced on behalf of the State to rebut the defendant's evidence of insanity. ${ }^{42}$

Once it is determined that expert testimony regarding the battered women's syndrome is relevant to the defendant's claim of self-defence, the next level of analysis concerns its admissibility. In order to evaluate this point to be settled, courts have adopted a three branched test: $:^{43}$

(1) The subject matter must be so distinctively related to some science, profession, business or occupation as to be beyond the ken of the average laymen."

(2) The witness must have sufficient skill, knowledge, or experience in that field or calling as to make it appear that his opinions or inferences will probably aid the trier of fact in their search for truth..$^{45}$

(3) Expert testimony is inadmissible if the state of the pertinent art or scientific knowledge does not permit a reasonable opinion to be asserted even by an expert..$^{46}$

The battered woman defendant who is charged with killing her batterer comes to court as a victim of what has often been years of abuse and is asked to account for the killing of a person who is typically unarmed, asleep or has his back turned. ${ }^{47}$ Where the testimony sought to be admitted by an expert relates to the reasonable fears of a defendant which can be comprehended by an average juror, the court is not in error to exclude expert testimony. ${ }^{48}$ The difficulty with expert testimony regarding battered women's syndrome is that it would appear as if the expert is teaching the

41. State v. Necaise 466 So. 2 d 660 (La. App. 5 Cir., 1985).

42. Smith v. State 277 S.E. 2 d 678 (Ga., 1981) See also State v. Baker 424 A. 2 d 171 (N.H., 1980) where testimony regarding the battered woman's syndrome was of fered by the state to rebut the defendant's evidence on the issue of insanity by providing an alternate explanation for the defendant's assault on his wife. The State contended that the alleged attempted murder was but a single episode in a recurring pattern of domestic violence and was neither caused nor produced by insanity. The defendant argued that testimony on the subject of battered wives was only marginally relevant but highly prejudicial, the court disagreed.

43. Supra n. 34.

44. Dyas v. United States 376 A. 2 d 827 (D.C., 1977) at 832.

45. Id.

46. Id. This test is a derivitive of the test set out in Frye v. United States 293 F. 1013 (D.C., 1923) at 1014:

... just when a scientific principle or discovery crosses the line between the experimental and demonstrable stages is difficult to define. Somewhere in this twilight zone the evidential force of the principle must be recognized, and while courts will go a long way in admitting expert testimony deduced from a well-recognized scientific principle or discovery, the thing from which the deduction is made must be sufficiently established to have gained general acceptance in the particular field in which it belongs.

47. K. McKinnie, "The Use of Expert Testimony In The Defense of Battered Women" (1981) 52 U. of Colorado L.R. 587.

48. Mullis v. State 282 S.E. $2 \mathrm{~d} 334$ (Ga., 1981). 
jury about something they know as well as anyone else, namely the reasonableness of a person's fear of imminent serious danger. However, that is not the objective of the testimony. The testimony is targeted at an area where the purported common knowledge of the jury may be very much mistaken, an area where jurors' logic, drawn from their own experiences, may lead to a wholly incorrect conclusion, an area where expert knowledge would enable the jurors to disregard their prior conclusions as being common myths rather than common knowledge ${ }^{99} \mathrm{Dr}$. Lenore Walker outlines the problem as follows: ${ }^{50}$

\begin{abstract}
The battering of women, like other crimes of violence against women, has been shrouded in myths. All of the myths have perpetuated the mistaken notion that the victim has precipitated her own assault. Some of them served as a protection against embarrassment. Others were created to protect rescuers from their own discouragement when they were unsuccessful in stopping the brutality. It is important to refute all the myths surrounding battered women in order to understand fully why battering happens, how it affects people, and how it can be stopped.
\end{abstract}

A defendant ought to have the right to explain her conduct both leading up to and following an offence..$^{31}$ In this respect the expert serves to educate the jury about a subject matter that is beyond their common understanding and which may only appear reasonable within a battering relationship.

This testimony is not offered with the purpose of invading the province of the jury, or preempting their function by speaking too directly to the ultimate issue (ie. guilt or innocence). Wigmore stated in 1940 that the rule that an opinion ought not to be allowed which would usurp the functions of the jury is so misleading and unsound that it should be entirely repudiated..$^{32}$ Today the accepted rule is that expert opinion on issues to be decided by the jury, even the ultimate issue, is admissible where the conclusion of the expert is one which jurors would not ordinarily be able to draw for themselves (ie. the conclusion is beyond the ken of the average layman)..$^{53}$ The ultimate issue rule has, over time, been reduced to a prohibition only against questions to an expert which in effect, submit the whole case to an expert witness for decision. Therefore, expert testimony explaining why a battered woman would not leave her spouse, would not inform police or friends of her circumstances, and would fear increased aggression against herself, would be such conclusions that typical jurors might not draw for themselves. For these reasons, courts have held that such testimony would not as a matter of law invade the province of the jury.

The threshold degree of skill, knowledge, education or experience in a particular area, which qualifies the expert to render an opinion regarding a matter within that area is within the discretion of the trial courts. However, few have specifically suggested the minimum criteria needed to allow such testimony. A physician trained in internal medicine may proffer testimony with respect to medical treatment but may not explain why battered women tend to remain with their spouses, ${ }^{54}$ nor may a crisis center counsellor with

49. State v. Kelly supra n. 24.

50. Supra n. 8 at 18.

51. People v. Minnis 455 N.E. 2 d 209 (1ll. App. 4 Dist., 1983).

52. Wigmore on Evidence, Vol. VII, Paragraph 1920 - 1921 (3d Ed., 1940) at 17 - 19.

53. Smith v. State supra n. 42.

54. People v. White 414 N.E. 2d 196 (IIl. App., 1980). 
no degree offer such testimony..$^{35}$ The function of this threshold is to set a minimum standard of expertise sufficient to qualify a person as an expert. The actual experience is a factor with respect to the competence of the witness to testify as an expert. Surely, if the state of the pertinent field permits a reasonable opinion to be asserted, then that opinion may be asserted by a qualified expert. Some courts have even gone so far as to allow an expert to testify regarding battered women's syndrome who have never personally examined or interviewed the defendant provided the facts upon which the opinion was based were on record. ${ }^{56}$ Most authorities agree that the witness ought to personally interview the defendant before rendering an opinion.

No other requirement to be met before expert opinion would be admitted into evidence has received more attention than the condition that the opinion must be shown to be generally acceptable within the experts particular scientific field. Some early decisions gave the following reasons for rejecting proffered expert testimony: ${ }^{37}$

We are not saying that this type of expert testimony is not admissible; we are merely holding that the state of the art was not adequately demonstrated to the court, and because of inadequate foundation the proposed opinions would not aid the jury.

The court in Ibn - Tamas v. United States remanded the case because the trial court had failed to rule on the expert's qualifications and whether the expert's methodology received a general acceptance..$^{s 8}$ On remand, the lower court concluded that the defendant failed to establish a general acceptance by the expert's colleagues of the methodology used. The case was again appealed and the Appellate Court held that: ${ }^{59}$

Frye requires the profferor of the expert on a new scientific theory to show that the evidence is not still in the experimental stage but has gained a scientific acceptance substantial enough to warrant an exercise of judicial discretion in favour of admissibility.

Similarily, in Hawthorne v. State the court concluded that expert testimony on battered woman's syndrome would aid the jurors. ${ }^{60}$ The case was remanded for the trial court to determine whether the expert was qualified and the extent to which her methodology was generally accepted. ${ }^{11}$ On remand, the trial court refused to allow the expert testimony, finding the expert was not qualified. However, the Court of Appeal in granting another remand invited the defence to re-offer the same witness "or any other witness as an expert on this subject". ${ }^{62}$

The tide has shifted from uncertainty to a substantial scientific and legal acceptance sufficient to warrant admissibility. The term "battered wife syndrome" was challenged in The State v. Gallegos, and the court held that since: ${ }^{63}$

55. State v. Moore 695 P. $2 d 985$ (Or. App., 1985).

56. Fennell v. Goosby 630 F. Supp. 451 (E.D. Pa., 1985).

57. Buhrle v. State 627 P. 2d 1374 (Wyo., 1981) at 1378.

58. Supra n. 34.

59. Ibn - Tamas v. United States 455 A. 2d 893 (D.C., 1983).

60. Hawthorne v. State 408 So. 2d 801 (Fla. App., 1982).

61. Id.

62. Hawthorne v. State 470 So. $2 \mathrm{~d} 770$ (Fla. App. 1 Dist., 1985) at 774.

63. Supra n. 21 at 1274. 
... the battered wife "syndrome" had gained general recognition and acceptance in the field of psychology. We, therefore, see no reason for excluding the use of a recognized term to describe the phenomenon.

The court in The State v. Allery also held that the battered woman's syndrome is a recognized phenomenon in the psychiatric profession, and is defined as a technical term of art in professsional diagnostic textbooks. ${ }^{64}$ Indeed, the New York Supreme Court has held that: 65

\begin{abstract}
The theory underlying the battered woman's syndrome has indeed passed beyond the experimental stage and gained a substantial enough scientific acceptance to warrant admissibility . . . numerous articles and books have been published about the battered woman's syndrome; and recent finding of researchers in the field have confirmed its presence and thereby indicated that the scientific community accepts its underlying premises.
\end{abstract}

Further, the Supreme Court of Kansas has held that: ${ }^{: 6}$

... this field has been researched for ten years with extensive publications and articles, and four or five books written on the subject matter of the battered woman syndrome ... it is noted in the American Medical Association Journal, in social worker's journals, and in experimental and clinical psychologists' journals and that papers from conferences on domestic violence cover the topic.

The court in The State v. Kelly recognized three ways a proponent of scientific evidence can prove its general acceptance and thereby its reliability: ${ }^{67}$

(1) by expert testimony as to the general acceptance, among those in the profession, of the premises on which the proffered expert witness based his or her analysis;

(2) by authoritative scientific and legal writings indicating that the scientific community accepts the premises underlying the proffered testimony; and

(3) by judicial opinons that indicate the expert's premises have gained general acceptance.

The court held that based upon its criteria (noted above), the battered woman's syndrome has a sufficient basis to produce uniform and reliable results.

It is clear that the state of the art has crossed the line delimitated in Frye v. United States between the experimental and the demonstrable in that a reasonable opinion may be asserted by an expert. ${ }^{68}$ If the three fold test, above, is met and the testimony is relevant then it will be admissible to support the defendant's claim of self-defence.

While the trial court has a broad discretion in determining the range of subjects on which an expert may be allowed to testify, ${ }^{69}$ if there is a clear error in the court's refusal to allow expert testimony consistent with a theory of self-defence, then its decision may be disturbed on appeal. ${ }^{70}$

64. State v. Allery 682 P. $2 \mathrm{~d} 312$ (Wash., 1984).

65. People v. Torres 488 N.Y.S. 2 d 358 (Sup., 1985) at 363.

66. State v. Hodges 716 P. $2 d 563$ (Kan., 1986) at 568.

67. State v. Kelly supra n. 24 at 380.

68. Frye v. United States supra, footnote 46 . The only express rejection of the battered woman's syndrome appears in the case of State v. Thomas 423 N.E. 2 d 137 (Ohio, 1981) at 140 n. 3:

Even if the facts in Ibn - Tamas were similar to the case at bar, we reject its rationale and decline to follow it.

See M.K. Jenson, "State v. Thomas: The Final Blow to Battered Women" (1982) 43 Ohio

State L.J. 491 for a discussion of how this case is not in line with current legal practice.

69. Supra n. 62.

70. State v. Anaya 438 A. 2 d 892 (Me., 1981). 
However, if counsel makes a strategic decision to assert another defence, ${ }^{\prime \prime}$ or does not give the court an opportunity to determine the admissibility of the expert's testimony, then there exists no record of an error that a defendant could contest upon appeal. ${ }^{2}$ Since evidence to support a battered woman's defence is generally available before the trial, courts have held that failure to lead testimony regarding the battered woman's syndrome does not meet the test of newly discovered or fresh evidence. ${ }^{73}$ If a new trial is granted for any reason, the defendant will have an opportunity, if she chooses, to develop those issues for the trial court's consideration. ${ }^{74}$

\section{THE BATTERED WOMAN'S DEFENCE IN CANADA}

Despite the widespread public attention the battered woman's defence has received in the United States there have been no recorded cases in Canada. This does not mean that a woman who kills her batterer in the reasonable belief that the action was necessary to prevent her death or serious injury will not be exonerated in this country. What it does mean is that to date Canadian juries have not had the benefit of expert testimony regarding the cumulative results of psychological stresses that result from the deliberate and repeated infliction of mental and physical abuse. The following will demonstrate that there are no bars to the successful application of this defence in Canadian courts.

Two primary sections of the Canadian Criminal Code may be employed by the battered woman claiming self-defence. ${ }^{75}$ Section $34(2)$ of the Criminal Code applies if the defendant causes death or grievous bodily harm in defending herself: ${ }^{76}$

34.(2) Every one who is unlawfully assaulted and who causes death or grievous bodily harm in repelling the assault is justified if

(a) he causes it under reasonable apprehension of death or grievous bodily harm from the violence with which the assault was originally made or with which the assailant pursues his purposes, and

(b) he believes on reasonable and probable grounds, that he cannot otherwise preserve himself from death or grievous bodily harm.

In considering the application of s. 34(2), the Supreme Court of Canada unanimously held that:"

Section $34(2)$ is invoked where death or grievous harm has resulted but:

(i) the accused reasonably apprehended his own death or grievous harm, and

(ii) he believed on reasonable grounds that he had no other means of avoiding his own death or grievous harm . . . Secion 34(2) affords justification where there was an intention

71. Meeks v. Bergen 749 F. 2 d 322 (U.S. App. 6 Circ., 1985).

72. State v. Leaphart 673 S.W. 2d 870 (Tenn. Cr. App., 1983); Ward v. State 470 So. 2d 101 (Fla. App. 1 Dist., 1985).

73. People v. Powell 442 N.Y.S. 2d 645 (App. Div., 1981).

74. Borders v. State 433 So. 2 d 1325 (Fla. App. 3 Dist., 1983).

75. The Criminal Code S.C. 1953 - 54, c. 51, ss. 34, 37.

76. Id. s. 34.

77. Brisson v. The Queen (1982) 69 C.C.C. (2d) 97 (S.C.C.) at 119. 
to cause death but under circumstances where objectively it was reasonable that the person accused believed he was going to be killed and subjectively he did so believe. Section 34(2) obviously provides for acquittal, despite the fact that the accused means to cause death or bodily harm that he knows is likely to cause death.

It should be noted that provided the two conditions noted above are satisfied, there is not statutory requirement that the defendant must have been able to retreat, or attempted to retreat in the face of an attack. ${ }^{78}$ The ability to retreat should be simply a factor considered in deciding whether it was necessary to use force, and whether the force was reasonable. ${ }^{79}$ Surely the battered woman will be able to claim the protection of this provision.

The Ontario Court of Appeal in considering the degree of force used in self-defence held that there is no specific requirement in Section 34(2) that the repelling force used by the defendant shall be proportional to the unlawful assault: ${ }^{80}$

Whether the amount of force used against the accused was disproportionate to the nature of the force used by her was proper to be considered by the jury as a circumstance, or an item of evidence, in deciding whether she had a reasonable apprehension of death or grievous bodily harm and whether she had reasonable and probable grounds to believe that she could not otherwise preserve herself from death or grievous bodily harm. If, however, the jury was either satisfied that the accused has such apprehension and belief, or entertained a reasonable doubt with respect to it, she was entitled to be acquitted. No further requirement existed that the force used by the accused be proportionate to the nature of the attack upon her.

Section 34(2) provides justification for using force where the person has acted under a reasonable apprehension of death or grievous bodily harm from the unlawful assault and had believed, on reasonable and probable grounds, that she could not otherwise preserve himself from such death or harm. ${ }^{81}$ As in the American test set out in Brown v. United States what is required is a reasonable, though not necessarily correct judgement. ${ }^{82}$ Martin J.A. of the Ontario Court of Appeal stated that: $:^{83}$

The doctrine of mistake of fact is applicable to ...s.34(2). An accused's belief that he was in imminent danger from an attack may be reasonable, although he may be mistaken in his belief. Moreover, in deciding whether the force used by the accused was more than was necessary in self-defence under . . s. s4(2) the jury must bear in mind that a person defending himself against an attack, reasonably apprehended, cannot be expected to weigh to a nicety, the exact measure of necessary defensive action.

The second provision that a battered woman may be able to take shelter under with respect to a self-defence claim is section 37 of the Criminal Code. This section has received comparatively little judicial attention and has been employed primarily where a defendant acts in defence of a person under her protection rather than herself. The section provides that:

78. M. Rosenberg, Self Defence and Defence of Property, National Criminal Law Program, Substantive Criminal Law, vol. 3 (1986).

79. $R$ v. Deegan (1979) 49 C.C.C. (2d) 417 (Alta. C.A.); $R$ v. Ward (1978) 4 C.R. (3d) 190 (Ont. C.A.).

80. $R$ v. Bogue (1976) 30 C.C.C. (2d) 403 (Ont. C.A.) at 411.

81. Supra n. 78.

82. Supra n. 23.

83. $R$ v. Baxter (1975) 27 C.C.C. (2d) 96 (Ont. C.A.).

84. Supra n. 75, s. 37. 
37.(1) Everyone is justified in using force to defend himself or any one under his protection from assault, if he uses no more force than is necessary to prevent the assault or the repetition of it.

(2) Nothing in this section shall be deemed to justify the wilful infliction of any hurt or mischief that is excessive, having regard to the nature of the assault that the force used was intended to prevent.

This section of the Criminal Code deals with the justification for preventing an assault. It applies with respect to the charge of murder and differs from s.34(2) in that it incorporates the concept of "proportionate force" in self-defence. If this section is to be left with a jury it is incumbent upon a trial judge to distinguish its wording from that of s.34(2) which does not require that the force used be proportionate to the nature of the attack upon the defendant. Recently the Appeal Division of the Nova Scotia Supreme Court had the occasion of reviewing this section of the Criminal Code in the case of $R$. v. Whynot.$^{85}$ They held that: ${ }^{86}$

\begin{abstract}
A person who seeks justification for preventing an assault against himself or someone under his protection must be faced with an actual assault, something that he must defend against, before the provisions of s.37 can be invoked, and that assault must be lifethreatening before he can be justified in killing in defence of his person or that of someone under his protection ... Under 5.37 the assault must be such that it is necessary to defend the person assaulted by the use of force. No more force may be used than necessary to prevent the assault or the repetition of it. In my opinion, no person has the right in anticipation of an assault that may or may not happen, to apply force to prevent the imaginary assault.
\end{abstract}

In Whynot the defendant killed her abusive common law husband after an extended period of escalating violence cumulating in the threat of "burning out" a neighbour and "dealing" with her son. The Court of Appeal overturned the case citing as the primary reason, that they could find little in the record from which a jury could reasonably infer that the impending assault was a certainty. ${ }^{87}$ This case surely opened the door in Canada with respect to establishing, upon expert testimony, the state of mind of a battered woman who perceives herself or members of her family in imminent physical danger at the time she killed her batterer.

The admission of previous acts of violence by the victim in a murder trial to support a claim of self-defence and establish a state of mind is not a new phenomenon in Canada. Archambault, J. in 1909 admitted evidence tending to show that: ${ }^{88}$

The deceased has beaten members of his family and put them in danger of their lives on several occasions during a period of seven years prior to the fatal conflict, all of which was known to the accused and would have affected the latter's state of mind as to the danger to be apprehended when his father, on the day of the fatal conflict, threatened to first kill the mother of the accused and afterwards to kill the accused, and gave the accused reason to believe that his father would, if not prevented, carry out his threats.

85. $R$ v. Whynot (Stafford) (1983) 9 C.C.C. (3d) 449 (N.S.S.C. [App. Div.]).

86. Id. at 464.

87. On February 14, 1984, at her new trial, Jane Marie Stafford (Whynot) plead guilty to the charge of manslaughter. Her punishment was fixed at six months imprisonment and two years probation. Ironically, Jane saw this as her first step toward freedom after years of psychological imprisonment.

88. $R$ v. Drouin (1909) 15 C.C.C. 205 (Que. Q.B.) at 206. See also R v. Scott (1910) 15 C.C.C. 442 (Ont. H.C.J.). 
In $R$. v. Conway the Ontario Court of Appeal recently considered the appropriate direction to a jury when evidence is led of prior acts of violence: ${ }^{89}$

Substantial evidence was adduced at trial with respect to previous acts of violence perpetrated by [the deceased] Leach ... . The trial Judge did not instruct the jury as to the use of which they could put such evidence. He should have instructed the jury that the evidence of the prior acts of violence and intimidation by Leach could support an inference that Leach had a disposition for violence of a kind likely to result in conduct of a kind that might cause a victim of such violence to consider it life-threatening and could be considered in support of the appellant's version of the events of August 29, 1982 [The day of the killing].

He should also have further instructed the jury that the evidence with respect to the appellants' prior acts of violence could be considered by them as relevant in considering the issue of who was the aggressor in the altercation.

It should also be noted that evidence of prior acts of violence by the victim are admissible even though the acts are not known to the accused..$^{\circ 0}$ This evidence is admissible and relevant in demonstrating the probability of the victim being the aggressor during the incident in question, if there is some other evidence of the victim's aggression on record. This supplemental evidence may be supplied by the defendant or other witnesses. To meet the test of relevancy this evidence must merely be able to reasonably assist the jury in coming to a just verdict with respect to a claim of self-defence."1

As in the American example, the burden of disproving self-defence is on the crown throughout and the trial Judge is under a duty to relate specifically the principles of reasonable doubt to the jury. ${ }^{92}$ In fact, the Ontario Court of Appeal stated that: $:^{93}$

The burden was not upon the accused to show conclusively that the mode of defending himself was necessary to preserve his life or to avoid serious bodily harm, nor any of the other matters set forth in that part of the charge first quoted ...

Further, the Supreme Court of Canada in Latourv. The King held that once the jury is properly instructed as to what the law recognizes as ingredients of self-defence, the appropriate question for them becomes not whether the defendant has established such ingredients but whether the evidence indicates them. ${ }^{94}$ The jury must be directed that should they find affirmatively, or be left in doubt on the question put to them, then the accused is entitled to a full acquittal..$^{95}$

In Cadwallader, Sirois J. held that: ${ }^{\circ}$

When the defence of self-defence is raised it does not affect the burden upon the Crown of establishing its case - that is of proving the accused guilty of the offence beyond a reasonable doubt. All that the accused has to do to establish this defence is introduce evidence raising at least a reasonable doubt as to his guilt; the burden rests on the prosecution of negativing that defence. If, on consideration of the whole of the evidence,

89. $R$ v. Conway (1985) 17 C.C.C. (3d) 481 (Ont. C.A.) at 488.

90. $R$ v. Scopelliti (1981) 63 C.C.C. (2d) 481 (Ont. C.A.).

91. Supra n. 78; $R$ v. Dubois (1976) 30 C.C.C. (2d) 412 (Ont. C.A.); $R$. v. Scott supra n. 88; $R$ v. Callahan (1915) 26 C.C.C. 93 (Alta. S.C.).

92. $R$ v. Deegan supra n. 79; $R$ v. Philbrook (1941) 77 C.C.C. 26 (Ont. C.A.); Latourv. The King (1950) 98 C.C.C. 258 (S.C.C.); Picariello v. the King (1923) 39 C.C.C. 229 (S.C.C.).

93. R. v. Philbrook Id. at 28.

94. Latour v. The King supra $n$. 92.

95. A.W. Mewett, M. Manning, Criminal Law (2d. ed., 1985).

96. R. v. Cadwallader [1966] 1 C.C.C. 380 (Sask. Q.B.) at 388. 
the jury are either convinced of the innocence of the prisoner or are left in doubt whether he was acting in necessary self-defence they should acquit.

The first and general requirement of admissibility is relevancy. ${ }^{97}$ As stated earlier, expert testimony regarding the battered woman's syndrome is offered for the purpose of dispelling common myths about battered women as well as demonstrating the reasonableness of her fear in anticipating death or serious bodily harm. This evidence is central to the battered woman's defence and far outweighs any prejudicial effect of labeling the victim as a batterer ${ }^{98}$ This is especially true since evidence of prior acts of violence by the victim will most certainly be admitted.

The next step is to consider the admissibility of the expert testimony. Canadian Courts have adopted a three-fold test similar to that adopted in Ibn - Tamas v. United States ${ }^{99}$ and Dyas v. United States: ${ }^{100}$

(1) The subject matter of the inquiry must be such that ordinary people are unlikely to form a correct judgment about it, if unassisted by persons with special knowledge. ${ }^{101}$

(2) The witness offering expert evidence must have gained his special knowledge by a course of study or previous habit which secures his habitual familiarity with the matter in hand, ${ }^{102}$

(3) Expert testimony may be inadmissible if the state of the pertinent art or scientific knowledge does not permit a reasonable opinion to be asserted even by an expert. ${ }^{103}$

In considering the first branch of this test the Supreme Court of Canada has held that: ${ }^{104}$

... expert opinion evidence will be admitted where it will be helpful to the jury in their deliberations and it will be excluded only where the jury can as easily draw the necessary inferences without it. When the latter is the situation, the intended opinion evidence is superfluous and its admission would only involve an unnecessary addition to the testimony placed before the jury ...

It is clear, as noted in the first branch of the American test, that without expert testimony regarding the battered woman's syndrome a jury may

97. Cloutier v. The Queen (1979) 48 C.C.C. (2d) 1 (S.C.C.).

98. Noor Mohamed v. The King [1949] A.C. 182 (P.C.); $R$ v. Wray [1970] 4 C.C.C. 1 (S.C.C.).

99. Supra n. 34.

100. Supra n. 44.

101. Kelliher v. Smith [1931] S.C.R. 672 at 684.

102. Id.

103. The Manitoba courts in particular have considered this issue. In R. v. Medvedew (1978) 43 C.C.C. (2d) 434. O'Sullivan, J.A. in his dissenting judgment adopted the reasoning in Fryev. United States supra n. 46 and states at 497 that:

I do not know whether that test has been adopted in Canadian Courts or not but to me it makes sound sense and expresses a view in accord with the principles of the common law. This view has subsequently been quoted with approval in $R$. v. Neilson and Stolar (1984) 16 C.C.C. (3d) 39 (Man. C.A.) and followed in R. v. K. (1979) 47 C.C.C. (2d) 436 (Man. Prov. Ct.) [Fam. Div]).

104. R. v. Fisher (1961) 130 C.C.C. 2 at 19; affd. (1961) 130 C.C.C. 1 (S.C.C.). See R. v. Dubois supra n. 91; where Martin J.A. states at 414 that:

The proferred psychiatric evidence was not admissable, since ordinary men and women are able to make a judgement on such a matter and are unable to receive appreciable assistance from expert testimony.

It is assumed that the converse would be true in that if the evidence would assist the jury in their deliberations, then it would be admissable. 
yield an uniformed and incorrect disposition. In considering whether expert testimony would usurp the function of the jury the Ontario Court of Appeal held that: ${ }^{\text {:os }}$

In Canada the ultimate issue doctrine may now be regarded as having been virtually abandoned or rejected. Where evidence has been rejected on the basis of the doctrine, such rejection can be explained on other grounds. In some instances the opinion evidence should be rejected because the trier of fact, whether Judge or jury, is just as well qualified as the witness to draw the necessary inference. Accordingly, the non-expert testimony is superfluous, as it is of no appreciable assistance to the Judge or jury. Alternatively, the admission of evidence on the ultimate issue can be justified on the basis that the witness is an expert and the Judge or jury requires his assistance.

In considering the second branch of this test the Supreme Court of Canada held that: ${ }^{106}$

... a witness may not give his opinion upon matters calling for special skill or knowledge unless he is an expert in such matters nor will an expert witness be allowed to give his opinion upon matters not within his particular field.

An expert witness is one: ${ }^{107}$

... who by experience has acquired special or peculiar knowledge on the subject of which he undertakes to testify, and it does not matter whether such knowledge has been acquired by study of scientific works or by practical observation.

Therefore, if a person meets a minimum threshold of skill, knowledge, education or experience in understanding the behavior of battered women, then that person ought to be qualified as an expert witness.

The third branch of both the American and Canadian tests are virtually identical. ${ }^{108}$ As discussed earlier there can be no doubt that the state of the art has passed from the experimental to the demonstrable. Today the battered woman's syndrome has gained general acceptance among the psychiatric and psychological communities. Many authoritative scientific and legal publications and several judicial opinions accept the premises underlying the syndrome and find them reliable. If the correct circumstances arise there is no reason why the battered women's defence should not prove successful in Canadian Courts.

\section{CONCLUSION}

Gradually, the age-old problem of wife abuse is becoming recognized as a significant crisis in modern society. Research into the problem is bringing to light discoveries which can aid juries in the recognition of the state of mind unique to battered women who kill in self-defence. In light of the recognition and acceptance of these discoveries, courts are under a duty to respond, by admitting expert testimony where it is used to support the selfdefence claim of a battered woman charged with murder. The testimony is relevant and satisfies all of the qualifications regarding admissibility of expert opinion in Canada,

While Canadian society cannot condone an intentional or retributive murder, it must address the problem of family violence by protecting the rights of a battered woman to act reasonably in self-defence when circumstances fit such a recognized justification.

105. R. v. Graat (1980) 55 C.C.C. (2d) 429 at 443 . See also R v. St. Pierre (1974) 3 O.R. (2d) 642 (Ont. C.A.).

106. R. v. Fisher supra n. 104 at 2.

107. Rice v. Sockett (1912) 8 D.L.R. 84 (Ont. Div. Ct.) at 85, Citing State v. Davis 33 S.E. 449 (S.C., 1899) at 450.

108. The Canadian standard may be somewhat less strict than the American. See n. 97. 